Первая мировая война, данная реформа давала шанс развитию страны, как процветающему государству.

$$
* * *
$$

1. Каршин В. Ю. Реформы П. А. Столыпина: перекрестки мнений современных историков // Известия высших учебных заведений. Поволжский регион. Гуманитарные науки. 2007. № 2. С. 3-9.

2. Рогалина Н. Л. Столыпинская аграрная реформа: современная историографическая ситуация // Уральский исторический вестник. 2008. № 2 (19). С. 25-31.

3. Видяйкин С. В., Котляров С. Б. Деятельность Крестьянского Поземельного банка в Симбирской губернии в процессе реализации столыпинской аграрной реформы // Вестник НИИ Гуманитарных наук при Правительстве Республики Мордовия. 2010. № 2. С. 72-77.

4. Котляров С. Б. Правовые особенности столыпинских аграрных преобразований начала XX века // Черные дыры в российском законодательстве. 2013. № 6. С. 36.

5. Румянцев Ф. П. Особенности правового обеспечения столыпинской и современной аграрной реформы России: дисс.... кандидата юрид. наук. Н. Новгород, 2004. 227 с.

6. Закон 14 июня 1910 г. об изменении и дополнении некоторых постановлений о крестьянском землевладении. СПб., 1911. С. 1272-1287.

7. Свод Законов Российской империи. Том 10. Землеустройство. Сборник законов и распоряжений. СПб., 1914. С. 1-126.

8. Котляров С. Б. Правовые особенности столыпинских аграрных преобразований начала XX века // Черные дыры в российском законодательстве. 2013. № 6. С. 36-39.

9. Государственный архив Ульяновской области (ГАУО). Ф. 46. Оп. 2. Д. 55. Л. 29.

10. Батуринский Д. А. Аграрная политика царизма и Крестьянский поземельный банк. М.: «Новая деревня», 1925. $144 \mathrm{c.}$

11. Видяйкин С. В., Котляров С. Б. К вопросу о переселенческой политике в начале ХХ в. (по материалам Симбирской губернии) // Вестник НИИ гуманитарных наук при Правительстве Республики Мордовия. 2009. Т. 12. № 2. С. 64-69.

\title{
Юрьев P.A. \\ Адольф Райнах о социальном акте и происхождении права
}

ФКОУ ВО Кузбасский институт ФСИН России (Россия, Новокузнеик)

doi:10.18411/spc-20-11-2017-22

idsp: 000001:spc-20-11-2017-22

В начале XX века Адольф Райнах (1883-1917), один из учеников Э. Гуссерля и представитель раннего «феноменологического движения» предложил достаточно оригинальную и в чем-то даже опередившую время собственную концепцию социальных актов в своей работе «Априорные основания гражданского права». В истории философии прошлого века изыскания А. Райнаха стали достаточно изолированным способом исследования, а разработка теории социальных актов стала в дальнейшем тщательно разрабатываться в традиции аналитической философии в фокусе исследования «речевого акта». Эта разработка подразумевала уже в качестве основания фундаментальное отношение «мышления-языка» вместо отношения «мышление-сознание». Забегая вперед, укажем, что в дальнейшем развитие теории речевых актов в аналитической философии нашло свое применение в аналитической юриспруденции Г.Л.А. Харта (проблема аскриптивных и дескриптивных высказываний)[1] и в работах Дж. Серла, касающихся темы «институциональных фактов» [5].

Однако, близость тематики и способы ее концептуализации позволяют говорить об А. Райнахе как предшественнике теории речевых актов в целом. Особое внимание этому обстоятельству уделяет современный исследователь К. Маллиган. Он говорит о том, что у А. Райнаха социальный акт не является ни ментальным действием, ни внелингвистическим, ни лингвистическим действием - это «фундаментально новое понятие», включающее в себя сразу три компонента $[4,35]$.В этом плане идеальный речевой и социальный акт - это определенные (1) слова, (2) обстоятельства соответствующие словам, и соответствующие им (3) намерения, выраженные в определенных действиях[2, 28].Это позволяет проводить параллели между творчеством А. Райнаха и творчеством Дж. Л. Остина, одного из основоположников лингвистической философии. 
Необходимо учитывать, что «слова» у А. Райнаха - это воплощение фиксированного подразумеваемого значения, «обстоятельства» - это априорные предпосылки социального акта. Например, в ситуации с «распоряжением» и «установлением» таковым будет то, что распоряжение предполагает лицо или лица, на которых оно направлено, а, например, установление не предполагает наличие лиц.

Таким образом, согласно К. Маллигану, соответствия социальных актов и внутреннего опыта у А. Райнаха представлены так:

1. сообщению соответствует убеждение

2. вопрошанию соответствует неопределенность

3. просьбе соответствует пожелание

4. распоряжению соответствует воля

5. обещанию соответствует воля

6. установлению соответствует воля

Предполагается, что вопрос имеет основание в неопределенности некоего положения дел, сообщение фундировано убеждением, просьба желанием, обещание, распоряжение и установление предполагают волю. Обещание при этом предполагает волю к собственному образу действий, а распоряжение к чужому образу действий.

Что делает социальные акты такими, что их индивидуальная реализация в мире имеет интерсубъективное значение? Забегая вперед, скажем - это основание зиждется на познании положений дел. И что касается такой сферы общественных отношений как право, то в праве существует множество фактических положений, но которые, в свою очередь, имеют свой источник, а именно сферу априорного познания.

А. Райнах пишет: «те образования, которые общепринято называть специфически правовыми, обладают бытием так же, как числа, деревья или дома; что это бытие независимо от того, постигается ли оно людьми или нет, что оно, в частности, независимо от какого бы то ни было позитивного права. Не только ложно, но и по своему последнему основанию бессмысленно считать правовые образования творениями позитивного права $<\ldots>$ В действительности имеет место то, что так ревностно оспаривается: позитивное право преднаходит те правовые понятия, которые входят в него; оно ни в коем случае их не производит» [3, 156].

Итак, согласно А. Райнаху, выражение акта является необходимым условием так называемого «социального акта» - «распоряжение и просьба не могут осуществляться чисто внутренним образом» [3, 175].Помимо внутренних актов, или актов, осуществляемых чисто внутренним образом, существуют «переживания направленные на другое лицо». Подобного рода переживания «проникают в другого», нужно, чтобы другой «им внял». «Все это социальные акты (просьба, увещевание, вопрошание, распоряжение, сообщение, обещание - Ю.Р.), которые тот, который их осуществляет, в ходе самого осуществления направляет другому лицу, чтобы закрепиться в его душе» $[3,176]$. Именно эти акты, предполагающие наличие «другого» и чтобы «им вняли» и являются социальными.

Таким образом, можно предположить, что в основе права как системы лежит некоторое трансцендентальное основание в виде столкновения «Я» как источника социального акта и «Другого», как адресанта распоряжения, установления, вопроса, обещания и т.д. В этом смысле природа «общественного договора» основана на априорных основоположениях, постигаемых имеющими волю субъектами. Правовые образования «преднаходятся» трансцендентальным сознанием и реализуются в конкретных правовых нормах.

$$
\text { *** }
$$

1. Оглезнев В.В. Г.Л.А. Харт и формирование аналитической философии права. - Томск: Изд-во Том.ун-та, 2012.

2. Остин Дж. Л. Слово как действие. /Новое в зарубежной лингвистике. Вып. XVII. M., 1986.

3. Райнах А. Априорные основания гражданского права. / Собрание сочинений. М.: ДИК, 2001.

4. Mulligan K. Promisings and other Social Acts: Their Constituents and Structure/Speech Acts and Sachverhalt. Reinach and the Foundations of Realist Phenomenology. - Doerdrecht: Martinus Nijhoff Publishers, 1987.

5. Searle J.R. Freedom and Neurobiology. Reflections on Free Will, Language and Political Power.Columbia University Press, New York, 2007. 